\title{
The effects of pharmaceutical and personal care products on the behavior of Burkholderia cepacia isolated from drinking water
}

\author{
I.B. Gomes ${ }^{\mathrm{a}}$, D. Madureira ${ }^{\mathrm{a}}$, L.C. Simões ${ }^{\mathrm{a}, \mathrm{b}}$, M. Simões ${ }^{\mathrm{a}, *}$ \\ ${ }^{a}$ LEPABE, Department of Chemical Engineering, Faculty of Engineering, University of Porto, Rua Dr. Roberto Frias, s/n, 4200-465, Porto, Portugal \\ ${ }^{\mathrm{b}}$ CEB - Centre of Biological Engineering, University of Minho, Campus de Gualtar, 4710-057, Braga, Portugal
}

\section{A R T I C L E I N F O}

\section{Keywords:}

Biofilms

Disinfection

Drinking water

Emerging contaminants

Pharmaceutical and personal care products

\begin{abstract}
A B S T R A C T
The presence of pharmaceutical and personal care products (PPCPs) in water environments has been extensively reported, particularly at trace concentrations in drinking water (DW). Nevertheless, there is a lack of information on the possible effects of the presence of PPCPs on the microbiota of drinking water distribution systems (DWDS). This pioneer study aims to understand the effects of exposure to selected PPCPs (antipyrine - ANTP, caffeine - CAF, carbamazepine - CBZ, clofibric acid - CA, diclofenac sodium salt - DCF, galaxolide - HHCB, ibuprofen - IBP, tonalide - AHTN, tylosin - TY and trimethoprim - sulfamethoxazole - TMP-SMX) on the motility and biofilm formation of Burkholderia cepacia, a bacterium isolated from a DWDS. The effects of PPCPs on the susceptibility of $B$. cepacia to sodium hypochlorite $(\mathrm{NaOCl})$ and to the antibiotic combination TMP-SMX was also determined. The results demonstrated that inactivation of $B$. cepacia with $\mathrm{NaOCl}$ was more difficult when in the presence of TMP-SMX, ANTP and CAF. Changes were also found on swarming motility. Biofilms formed in the presence of CBZ and TMP-SMX were more susceptible to $\mathrm{NaOCl}$ action. The selected PPCPs had no remarkable effects on swimming motility, biofilm production and susceptibility to TMP-SMX. The overall results emphasize that the presence of some PPCPs in DWDS influence bacterial behavior and decrease the efficiency of DWDS disinfection with chlorine, affecting the microbiological safety of the delivered water.
\end{abstract}

\section{Introduction}

In the last two decades several emerging contaminants, particularly pharmaceutical and personal care products (PPCPs) have been detected in finished drinking water (DW) (Benotti et al., 2009; Carmona et al., 2014; Stackelberg et al., 2004, 2007). Therefore, the concern about the hazards for human health emerged and several studies were performed to investigate the possible risks for consumers (Gaffney et al., 2015; Leung et al., 2013; Schriks et al., 2010; Snyder, 2008). Although no direct risks for human health were found, it is of utmost importance to evaluate possible effects on the microbiota present in drinking water distribution systems (DWDS), as the presence of biofilms in pipe walls is unavoidable. Microorganisms in DW do not represent a problem, unless pathogens are present or when there is excessive growth (Prest et al., 2016). As microbial communities populate DWDS, one cannot disregard the possible effect of PPCPs on their behavior. In this regard, some questions remain to be answered: Are PPCPs affecting the susceptibility of DW bacteria to disinfection? What are the consequences for microbiological DW safety? What are the public health hazards? In fact, the effects of PPCPs on non-targeted organisms in which PPCPs are not directly applied or used, were observed in the environment. Brodin et al. (2013) reported that a residual concentration $\left(1.8 \mu \mathrm{gl}^{-1}\right)$ of the anxiolytic oxazepam increased the locomotor activity and the feeding rate of the fish Perca fluviatilis; but diminished its sociability. In addition, the antidepressant fluoxetine, at $1 \mu \mathrm{g}^{-1}$, was reported to affect the matting behavior of the male population of Pimephales promelas (Weinberger and Klaper, 2014). The males increased the time they spent building the nest and, for higher concentrations, their interaction with females was reduced becoming more aggressive and showing repetitive behaviours (Weinberger and Klaper, 2014). Nitro- and polycyclic musks fragrances inhibited the activity of multidrug efflux transporters, liable for multixenobiotic resistance in the gills of the marine mussel Mytilus californianus (Luckenbach and Epel, 2005). The activity was only partially recovered after a period of 24-48 h.

Pharmaceuticals and some chemicals used in personal care products are designed to interfere with specific pathways and processes in biological systems (Boxall et al., 2012) and hence may affect the colonizing microorganisms. Furthermore, microorganisms can adapt to changes in the environment. Regarding the effects of PPCPs on microbial communities, Kraigher et al. (2008) demonstrated that the presence of five

\footnotetext{
* Corresponding author.

E-mail addresses: luciachaves@deb.uminho.pt (L.C. Simões), mvs@fe.up.pt (M. Simões).
} 
pharmaceuticals (ibuprofen, naproxen, ketoprofen, diclofenac and clofibric acid) at $50 \mu \mathrm{gl}^{-1}$, led to reduction of the diversity of a bacterial community in a small-scale wastewater treatment bioreactor. Also, Phan et al. (2016) observed a shift in bacterial community diversity when exposed to trace concentrations of 30 emerging contaminants, including PPCPs.

In DWDS, most bacteria are in biofilms attached to the pipe surfaces and only 5\% are in the bulk phase (Berry et al., 2006). The presence of biofilms in DWDS can affect the aesthetic quality of water, by deteriorating the taste, color and odor of the water (Liu et al., 2016). In addition, biofilms are known to harbor pathogens (Wingender and Flemming, 2011) which can compromises the microbiological safety of DW. Another emerging problem for the DW industry and for public health is the presence of antibiotics, antibiotic resistance genes (ARG) and antibiotic resistant bacteria (ARB) in finished DW (Bergeron et al., 2015, 2016; Xi et al., 2009; Ye et al., 2007). Therefore, it is necessary to understand if the presence of PPCPs can influence microbial behavior, particularly their susceptibility to disinfection. There is a hypothesis that PPCPs can contribute to the development of resistant bacteria (Daughton and Ternes, 1999). According to Boxall et al. (2012), this is one of the most important questions regarding PPCPs. Xi et al. (2009) suggested that DW treatment could increase microbial resistance to antibiotics or favor the transference of ARGs.

This work aims to assess the effects of PPCPs at residual concentrations on planktonic and sessile growth of a model bacterium isolated from DW, Burkholderia cepacia (Simões et al., 2007), and considered as emerging pathogen (Chaparro et al., 2001). Table 1 presents information on PPCPs and their trace concentrations detected in DW, providing background information for this study. The effects of the presence of PPCPs were also evaluated on $B$. cepacia susceptibility to sodium hypochlorite $(\mathrm{NaOCl})$ and to the antibiotic combination trimethoprim - sulfamethoxazole (TMP-SMX).

\section{Materials and methods}

\subsection{Emerging contaminants}

Eleven PPCPs were selected for this work: three nonsteroidal antiinflammatory drugs (NSAIDs) (antipyrine - ANTP - from Alfa Aesar (Karlsruhe, Germany); diclofenac sodium salt - DCF - from Fluka (Steinheim, Germany) and ibuprofen - IBP - from Alfa Aesar (Karlsruhe, Germany)), two musk fragrances (galaxolide - HHCB - and tonalide AHTN - both from Sigma-Aldrich (Steinheim, Germany)), one neuroactive drug (carbamazepine - CBZ - from Acros Organics, New Jersey,

Table 1

List of PPCPs selected for this study and respective concentrations found in DW. ${ }^{1}$ Cited from Jones et al. (2005).

\begin{tabular}{lll}
\hline PPCPs & $\begin{array}{l}\text { Concentration found in DW } \\
\left(\text { ng. } \mathrm{L}^{-1}\right)\end{array}$ & References \\
\hline AHTN & 0.51 & $\begin{array}{l}\text { Wombacher and Hornbuckle } \\
(2009)\end{array}$ \\
ANTP & 400 & $\begin{array}{l}\text { Reddersen et al. }(2002)^{1} \\
\text { Stackelberg et al. }(2004)^{1}\end{array}$ \\
CAF & 119 & Stackelberg et al. $(2004)^{1}$ \\
CBZ & 258 & Heberer and Stan $(1996)^{1}$ \\
CA & 170 & Stumpf et al. $(1996)^{1}$ \\
DCF & 6 & Wombacher and Hornbuckle \\
HHCB & 2.2 & (2009) \\
IBP & 3 & Stumpf et al. $(1996)^{1}$ \\
TMP- SMX & 1.7 and 8.2, respectively & Wang et al. (2011) \\
TY & 1.7 & Zuccato et al. $(2000)^{1}$ \\
\hline
\end{tabular}

DMSO - Dimethylsulfoxide, AHTN - Tonalide, ANTP - Antypiryne, CAF Caffeine, CBZ - Carbamazepine, CA - Clofibric acid, DCF - Diclofenac, HHCB Galaxolide, IBP - Ibuprofen, TMP - SMX - Trimethoprim - sulfamethoxazole, TY - Tylosin.
USA), one lipid regulator (clofibric acid - CA - from Acros Organics, New Jersey, USA), one veterinary antibiotic (tylosin - TY - from SigmaAldrich, Steinheim, Germany), one central nervous system stimulant (caffeine - CAF from Fluka (Steinheim, Germany)) and two antibiotics that are used in combination (CLSI, 2015) (trimethoprim - TMP and sulfamethoxazole - SMX, both from Alfa Aesar (Karlsruhe, Germany)).

Stock solutions of each PPCPs were prepared using dimethyl sulfoxide (DMSO) (Fisher Scientific, UK). The PPCPs were tested at the residual concentration (ng/L) found in DW ([DW]) (Table 1) or at concentrations $100 \times$ higher $(100 \times[\mathrm{DW}])-($ Table 1$)$. The final concentration of DMSO applied in all experiments was $1 \%(\mathrm{v} / \mathrm{v})$. Bacterial cells in the absence of any PPCPs and only in the presence of DMSO $(1 \% \mathrm{v} / \mathrm{v})$ were used as controls.

\subsection{Microorganism and culture conditions}

B. cepacia was isolated from DW according to Simões et al. (2007). B. cepacia was grown overnight in batch cultures of $25 \mathrm{ml}$ of R2A broth (Reasoner and Geldreich, 1985) in an incubator (Velp Scientifica FOC 215E, Italy) at $25 \pm 2{ }^{\circ} \mathrm{C}$ and under $150 \mathrm{rpm}$ agitation (shaker IKA KS 130 basic, Germany). Microorganisms were harvested by centrifugation (Eppendorf centrifuge 5810R, Germany) at $3777 \mathrm{~g}$ for $15 \mathrm{~min}$ and then the cells were ressuspended in sterile synthetic tap water (STW) or in adequate growth media (R2A broth, Luria Bertani broth or MullerHinton broth, accordingly the experiment to be performed). The cell density was adjusted to $10^{6}$ cells. $\mathrm{ml}^{-1}$, a concentration representative of the number of heterotrophic bacteria in DW (Prest et al., 2016). STW was used to evaluate the minimum bactericidal concentration (MBC) (Section 2.3) and it was composed of $100 \mathrm{mgl}^{-1} \mathrm{NaHCO}_{3}$ (Fisher Scientific, Leicestershire, UK), $13 \mathrm{mg}^{-1} \mathrm{MgSO}_{4} .7 \mathrm{H}_{2} \mathrm{O}$ (Merck, Darmstadt, Germany), $0.7 \mathrm{mg} \mathrm{l}^{-1} \mathrm{~K}_{2} \mathrm{HPO}_{4}$ (Aplichem Panreac, Darmstadt, Germany), $0.3 \mathrm{mg} \mathrm{l}^{-1} \quad \mathrm{KH}_{2} \mathrm{PO}_{4}$ (CHEM-LAB, Zedelgem, Belgium), $0.01 \mathrm{mg} \mathrm{l}^{-1}\left(\mathrm{NH}_{4}\right)_{2} \mathrm{SO}_{4}$ (Labkem, Barcelona, Spain), $0.01 \mathrm{mg} \mathrm{l}^{-1} \mathrm{NaCl}$ (Merck, Darmstadt, Germany), $0.001 \mathrm{mg} \mathrm{l}^{-1} \mathrm{FeSO}_{4} .7 \mathrm{H}_{2} \mathrm{O}$ (VWR PROLABO, Leuven, Belgium), $1 \mathrm{mg} \mathrm{l}^{-1} \mathrm{NaNO}_{3}$ (Labkem, Barcelona, Spain), $27 \mathrm{mgl}^{-1} \mathrm{CaSO}_{4}$ (Labkem, Barcelona, Spain), $1 \mathrm{mg}^{-1}$ humic acids (Sigma-Aldrich, Steinheim, Germany) as carbon source (EPA and NIST, 2011). Luria Bertani broth (LBB) was used to assess bacterial motility, Muller-Hinton broth (MHB) was used to assess antibiotic susceptibility and R2A broth was used to study biofilm formation and control.

\subsection{Minimum bactericidal concentration of $\mathrm{NaOCl}$}

The MBC of NaOCl (Acros Organics, New Jersey, USA) for B. cepacia was determined by the microdilution method according to Andrews (2001). $\mathrm{NaOCl}$ solutions were prepared in sterile distilled water and the concentrations tested ranged from 0.1 to $10 \mathrm{ppm}$. Briefly, $180 \mu \mathrm{l}$ of bacterial suspension prepared as described in Section 2.2 and containing selected PPCPs (at [DW] and $100 \times$ [DW]) was added to $20 \mu \mathrm{l}$ of $\mathrm{NaOCl}$ solutions, in a flat-bottom 96 -well polystyrene microtiter plate (Orange scientific, Braine-l'Alleud, Belgium). The microtiter plates were incubated at $25 \pm 2{ }^{\circ} \mathrm{C}$ and under agitation $(150 \mathrm{rpm})$ for $24 \mathrm{~h}$. Afterwards, $\mathrm{NaOCl}$ was neutralized using sodium thiosulfate (Labkem, Spain) at a final concentration of $5 \%(\mathrm{w} / \mathrm{v})$ for $10 \mathrm{~min}$ (BSI, 2009). Finally, $10 \mu \mathrm{l}$ of bacterial suspension from each well was transferred to R2A plates and incubated at $25 \pm 2{ }^{\circ} \mathrm{C}$ for $24 \mathrm{~h}$. Negative controls were performed with bacteria exposed to PPCPs with no $\mathrm{NaOCl}$ added. The MBC corresponded to the lowest concentration of $\mathrm{NaOCl}$ where the $B$. cepacia was unable to grow on the R2A agar plates (Johnson et al., 2002). All tests were performed in triplicates, twice.

\subsection{Antibiotic susceptibility}

The Kirby-Bauer disk diffusion susceptibility test was carried out according to the Performance Standards for Antimicrobial Susceptibility Testing of Clinical and Laboratory Standards Institute 
(CLSI, 2015) in order to assess if the presence of PPCPs influenced the susceptibility of B. cepacia to trimethoprim and sulfamethoxazole (TMPSMX). TMP-SMX were used in combination as recommended strategy to control B. cepacia growth (CLSI, 2015). Bacterial suspensions $(10 \mathrm{ml})$ were grown for one week in the presence of PPCPs at $100 \times[\mathrm{DW}]$ and subsequently resuspended in MHB as described in Section 2.2. The bacterial suspension was adjusted to 0.5 McFarland standard $\left(6 \times 10^{8} \mathrm{CFU} / \mathrm{ml}\right)$ (CLSI, 2015) and spread on Mueller Hinton agar (MHA) (Oxoid, England). Sterile disks with the combination of TMPSMX $(1.25 \mu \mathrm{g}-23.75 \mu \mathrm{g})$ were placed onto the centre of the inoculated plates to observe growth inhibitory effects. Plates with disks containing DMSO were also used as control. The plates were incubated at $25 \pm 2{ }^{\circ} \mathrm{C}$ for $24 \mathrm{~h}$ and the diameter of the inhibition zone (with no bacterial growth) was measured after incubation (CLSI, 2015). This was performed in duplicate, twice.

\subsection{Motility assay}

B. cepacia has two forms of motility: swimming and swarming (Ferreira et al., 2013; Henrichsen and Blom, 1975). To assess the influence of the selected PPCPs on B. cepacia swimming and swarming motilities, bacterial suspensions were grown in the presence of PPCPs at $100 \times[\mathrm{DW}]$ for one week and were ressuspended in LBB (Liofilchem, Roseto degli Abruzzi, Italy) to a final density of $10^{6} \mathrm{cells}^{\mathrm{m}} \mathrm{ml}^{-1}$ (Section 2.2). A volume of $15 \mu \mathrm{l}$ of each suspension was applied on the centre of plates containing 1\% tryptone (Merck, Darmstadt, Germany), $0.25 \% \mathrm{NaCl}$ (Merck, Darmstadt, Germany) and $0.3 \%$ or $0.7 \%$ (w/v) agar (VWR PROLABO chemicals, Leuven, Belgium) for swimming and swarming motilities, respectively (Butler et al., 2010; Stickland et al., 2010). Plates were then incubated at $25 \pm 2{ }^{\circ} \mathrm{C}$ and the motility halos were measured after 24,48 and $72 \mathrm{~h}$ of incubation. Each condition was tested in duplicate, twice.

\subsection{Biofilm formation and control}

The method for biofilm development was adapted from Stepánovic et al. (2000). Bacterial suspensions were prepared as described in Section 2.2 and ANTP, CBZ, HHCB and TMP-SMX at [DW] were the PPCPs selected to be tested on $B$. cepacia biofilm formation and control. Biofilms were developed in 96-wells microtiter plates in the presence of the selected PPCPs. These PPCPs were selected according to the effects observed in planktonic B. cepacia (ANTP increased B. cepacia tolerance to NaOCl and TMP-SMX; HHCB increased B. cepacia tolerance to TMPSMX and swarming motility) and CBZ recalcitrance in the environment (Li et al., 2016; Löffler et al., 2005; Vernouillet et al., 2010). A volume of $200 \mu \mathrm{l}$ of bacterial suspension was added to each well of a flat-bottom 96-wells microtiter plate (Orange Scientific, Belgium) to form biofilms for $24 \mathrm{~h}$, at $25 \pm 2{ }^{\circ} \mathrm{C}$, and under agitation (150 rpm). R2A broth was used as negative control. After $24 \mathrm{~h}$, the bacterial suspension was carefully removed and each well washed with $200 \mu$ l of STW. To determine the effect of $\mathrm{NaOCl}$ on bacterial sessile community exposed to PPCPs, the $24 \mathrm{~h}$ old biofilms were exposed to $\mathrm{NaOCl}$ at 0.5 and $5 \mathrm{ppm}$ for one hour (at $25 \pm 2{ }^{\circ} \mathrm{C}$ and at $150 \mathrm{rpm}$ ). The remaining wells were filled with $200 \mu \mathrm{l}$ of STW and used as negative disinfection control. After the incubation period, a neutralization step (Knapp et al., 2013) was performed using sodium thiosulfate at a final concentration of $5 \%$ $(\mathrm{w} / \mathrm{v})$. Following this, the biofilm from each well was resuspended in $200 \mu \mathrm{l}$ of saline water $(0.85 \%)$ and reserved in a microcentrifuge tube. Each well was scrapped for 1 min with pipette tips, according to Borges et al. (2014). This step was repeated three times. The biofilm culturability was assessed in duplicate with two repeats by enumeration of colony forming units (CFU) in R2A plates $\left(25 \pm 2{ }^{\circ} \mathrm{C}\right.$ for $\left.48 \mathrm{~h}\right)$.

\subsection{Statistical analysis}

Data were analyzed by analysis of variance (ANOVA) using the statistical program SPSS version 22.0 (Statistical Package for the Social
Table 2

B. cepacia susceptibility to $\mathrm{NaOCl}$. Range of $\mathrm{MBC}$ values of $\mathrm{NaOCl}(\mathrm{mg} / \mathrm{l})$ in the presence and absence of selected PPCPs at [DW] and at $100 \times[\mathrm{DW}]$.

\begin{tabular}{|c|c|c|c|}
\hline \multirow[t]{2}{*}{ Condition } & \multicolumn{3}{|c|}{$\operatorname{MBC}\left(\mathrm{mg} \cdot \mathrm{l}^{-1}\right)$} \\
\hline & [DW] & & $100 \times[\mathrm{DW}]$ \\
\hline B. cepacia & & {$[0.5-2.5]$} & \\
\hline DMSO & & {$[2.5-4.0]$} & \\
\hline AHTN & [1.0-4.0] & & {$[3.0-4.0]$} \\
\hline ANTP & {$[2-4.5]$} & & {$[4.5-5.0]$} \\
\hline CAF & [4.5-5.0] & & {$[4.5-5.0]$} \\
\hline CBZ & {$[2.0-4.5]$} & & {$[3.0-5.0]$} \\
\hline $\mathrm{CA}$ & [2.0-4.5] & & {$[3.0-5.0]$} \\
\hline DCF & [2.5-4.5] & & {$[4.0-5.0]$} \\
\hline НHCB & [2.0-4.5] & & {$[3.5-4.0]$} \\
\hline IBP & [2.5-4.5] & & {$[3.0-4.0]$} \\
\hline TMP-SMX & [4.5-5.0] & & {$[5.0-7.0]$} \\
\hline TY & {$[2.0-4.5]$} & & {$[3.5-4.0]$} \\
\hline
\end{tabular}

DMSO - Dimethylsulfoxide; AHTN - Tonalide; ANTP - Antypiryne; CAF Caffeine; CBZ - Carbamazepine; CA - Clofibric acid; DCF - Diclofenac; HHCB Galaxolide; IBP - Ibuprofen; TMP - SMX - Trimethoprim - sulfamethoxazole; TY - Tylosin.

Sciences). Statistical calculations were based on a confidence level $\geq 95 \%$ ( $P<0.05$ was considered statistically significant).

\section{Results}

\subsection{Effect of PPCPs on B. cepacia susceptibility to $\mathrm{NaOCl}$}

The MBC of $\mathrm{NaOCl}$ was determined under oligotrophic conditions (STW) in the presence of selected PPCPs at trace concentrations found in environment, [DW] and at $100 \times[\mathrm{DW}]$. The results are presented in Table 2 and MBC is presented as a range of values due to the low concentrations determined and the variability of bacterial growth within these ranges. Complete inactivation of B. cepacia occurred at concentrations comprised between 0.5 and $2.5 \mathrm{mgl}^{-1}$ of $\mathrm{NaOCl}$. However, the presence of DMSO decreased the efficiency of $\mathrm{NaOCl}$, with $\mathrm{MBC}$ between 2.5 and $4.0 \mathrm{mg} \mathrm{l}^{-1}$. These values were used as a solvent control and the effect of PPCPs were evaluated by comparison with DMSO control.

In general, the MBC was not significantly altered in the presence of PPCPs at [DW]. However, the presence of CAF and TMP-SMX were apparently responsible for a slight increase in the MBC to 4.5-5.0 $\mathrm{mg} \mathrm{l}^{-1}$, in both cases; although differences were not statistically significant. Increasing PPCPs to $100 \times$ [DW] influenced $\mathrm{NaOCl}$ action for most of the conditions studied. No change on the MBC was found for CAF. However, ANTP and DCF at $100 \times$ [DW] increased MBC to $4.5-5.0 \mathrm{mg} \mathrm{l}^{-1}$ and $4.0-5.0 \mathrm{mg} \mathrm{l}^{-1}$, respectively. TMP-SMX at $100 \times[\mathrm{DW}]$ was responsible for the most pronounced increase in MBC (5.0-7.0 $\left.\mathrm{mg} \mathrm{l}^{-1}\right)$.

\subsection{Effect of PPCPs on B. cepacia susceptibility to TMP-SMX}

Table 3 presents the inhibition halo caused by TMP-SMX after $B$. cepacia growth in the presence of PPCPs at $100 \times[\mathrm{DW}]$ for $7 \mathrm{~d}$. According to CLSI (2015), B. cepacia is classified as susceptible to TMP-SMX if the inhibition halo is $>16 \mathrm{~mm}$, intermediate susceptibility is considered if $11 \mathrm{~mm}<$ inhibition halo $<15 \mathrm{~mm}$. If the inhibition halo $<10 \mathrm{~mm}, B$. cepacia is classified as resistant to TMP-SMX. The inhibition halo was $>16 \mathrm{~mm}$ for all the conditions tested. Therefore, $B$. cepacia was classified as susceptible to TMP-SMX. Moreover, the exposure to the selected PPCPs did not change the susceptibility of $B$. cepacia to TMP-SMX $(P>0.05)$. Although the inhibition halo caused by the presence of TMP-SMX decreased after exposure to HHCB, this difference was not statistically significant $(P>0.05)$. In addition, the exposure to compounds with antimicrobial activities, such as CAF, TY 
Table 3

B. cepacia susceptibility to TMP-SMX. Inhibition halo of TMP - SMX, after B. cepacia exposure to PPCPs at $100 \times[\mathrm{DW}]$ for 7 days. Values are mean value \pm standard deviation.

\begin{tabular}{ll}
\hline Condition & Inhibition halo $(\mathrm{mm})$ \\
\hline B. cepacia & $28.6 \pm 1.1$ \\
DMSO & $27.9 \pm 3.0$ \\
AHTN & $27.6 \pm 1.3$ \\
ANTP & $26.0 \pm 1.4$ \\
CAF & $26.0 \pm 1.4$ \\
CBZ & $27.7 \pm 3.7$ \\
CA & $27.4 \pm 3.3$ \\
DCF & $27.1 \pm 1.1$ \\
HHCB & $25.6 \pm 1.3$ \\
IBP & $28.9 \pm 1.7$ \\
TMP-SMX & $26.4 \pm 0.1$ \\
TY & $26.9 \pm 1.5$ \\
\hline
\end{tabular}

DMSO - Dimethylsulfoxide; AHTN - Tonalide; ANTP Antypiryne; CAF - Caffeine; CBZ - Carbamazepine; CA Clofibric acid; DCF - Diclofenac; HHCB - Galaxolide; IBP Ibuprofen; TMP - SMX - Trimethoprim - sulfamethoxazole; TY - Tylosin.

and TMP-SMX did not alter significantly B. cepacia tolerance to this antibiotic combination $(P>0.05)$.

\subsection{Effect of PPCPs on B. cepacia motility}

B. cepacia grown in the presence of PPCPs at $100 \times[\mathrm{DW}]$ for $7 \mathrm{~d}$ was tested on their swimming and swarming motilities (Table 4). $B$. cepacia swimming motility was not significantly affected by the presence of PPCPs $(P>0.05)$. The presence of some PPCPs was responsible for slight changes in swarming motility, particularly for $72 \mathrm{~h}$ incubation. DCF and HHCB increased swarming motility in 13 and $12 \%$, respectively. On the other hand, swarming motility decreased in 10 and $14 \%$ when B. cepacia grown in the presence of CAF and to TMP-SMX. Nevertheless, such changes were not statistically significant $(P>0.05)$.

\subsection{Effect of PPCPs on B. cepacia biofilm formation and control}

Fig. 1 presents the $\log$ CFU.cm ${ }^{-2}$ of $24 \mathrm{~h}$ old biofilms grown in the presence of some PPCPs (ANTP, CBZ, HHCB and TMP-SMX) at [DW], before and after exposure to $\mathrm{NaOCl}$ at 0.5 and $5 \mathrm{mg} \mathrm{l}^{-1}$ for one hour. These PPCPs were selected mainly due to the effects observed on

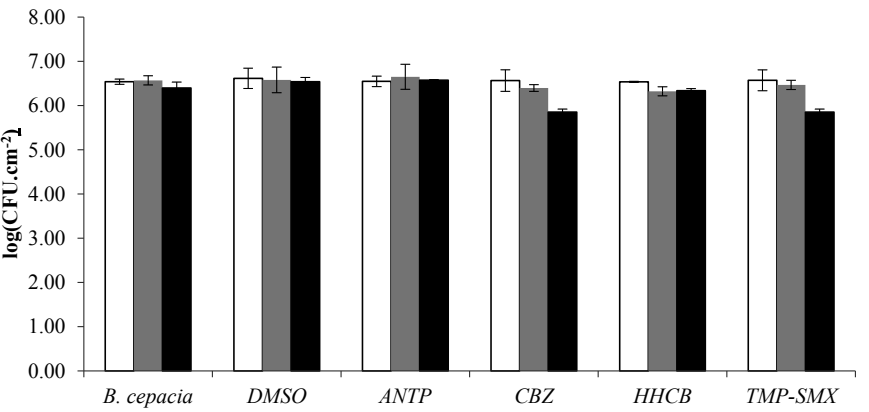

Fig. 1. B. cepacia biofilm formation for $24 \mathrm{~h}$ in the presence and absence of selected PPCPs at [DW] ( $\square$ - no treatment with $\mathrm{NaOCl}$ ). Biofilm treated with $\mathrm{NaOCl}$ at $0.5 \mathrm{mgl}^{-1}(\square)$ and $5 \mathrm{mgl}^{-1}(\square)$ for one hour. DMSO Dimethylsulfoxide; ANTP - Antypiryne; CBZ - Carbamazepine; HHCB Galaxolide; TMP - SMX - Trimethoprim - sulfamethoxazole.

planktonic B. cepacia: ANTP increased B. cepacia tolerance to $\mathrm{NaOCl}$ and TMP-SMX; HHCB increased B. cepacia tolerance to TMP-SMX and swarming motility; CBZ was selected based on its recognized recalcitrant properties, remaining in environment for long times with no degradation observed although the application of different technologies to PPCPs removal (Li et al., 2016; Löffler et al., 2005; Vernouillet et al., 2010).

The exposure to the selected PPCPs did not affect $B$. cepacia ability to form biofilms. In fact, log CFU.cm ${ }^{-2}$ were similar for all the conditions tested $(P>0.05)$. Biofilm susceptibility to $\mathrm{NaOCl}$ at $0.5 \mathrm{mg} \mathrm{l}^{-1}$ was also not altered in the presence of PPCPs $(P>0.05)$. An increase in $\mathrm{NaOCl}$ to $5 \mathrm{mgl}^{-1}$ increased $\log \mathrm{CFU} . \mathrm{cm}^{-2}$ reduction. However, complete reduction was not achieved. Moreover, biofilms formed in the presence of CBZ and TMP-SMX were more susceptible to $5 \mathrm{mgl}^{-1}$ $\mathrm{NaOCl}(P<0.05)$. The log CFU.cm ${ }^{-2}$ reductions of biofilms formed in the presence of CBZ and TMP-SMX were 0.71 and 0.72 , respectively (DMSO caused $0.08 \log$ CFU.cm ${ }^{-2}$ reduction). Biofilms formed in the presence of ANTP and HHCB had log CFU.cm ${ }^{-2}$ reductions similar to DMSO $(P>0.05)$.

\section{Discussion}

B. cepacia has been described as an opportunistic pathogen infecting immunocompromised patients mainly in cases of cystic fibrosis (Chaparro et al., 2001). The ability of $B$. cepacia to develop antibiotic resistance has also been described (Conway et al., 2003; Kuti et al., 2004; Moore et al., 2001). The presence of this bacterium in DW is not

Table 4

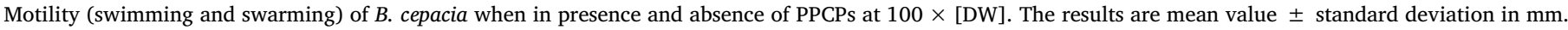

\begin{tabular}{|c|c|c|c|c|c|c|}
\hline \multirow[t]{3}{*}{ Condition } & \multicolumn{6}{|c|}{ Diameter halo $(\mathrm{mm})$} \\
\hline & \multicolumn{3}{|c|}{ Swimming } & \multicolumn{3}{|c|}{ Swarming } \\
\hline & $24 \mathrm{~h}$ & $48 \mathrm{~h}$ & $72 \mathrm{~h}$ & $24 \mathrm{~h}$ & $48 \mathrm{~h}$ & $72 \mathrm{~h}$ \\
\hline B. cepacia & $14.9 \pm 5.4$ & $32.3 \pm 4.0$ & $47.8 \pm 5.0$ & $7.6 \pm 1.6$ & $21.4 \pm 2.0$ & $30.6 \pm 0.5$ \\
\hline DMSO & $14.4 \pm 5.7$ & $32.8 \pm 3.1$ & $49.0 \pm 2.9$ & $7.6 \pm 0.9$ & $23.2 \pm 0.4$ & $32.6 \pm 3.4$ \\
\hline AHTN & $14.5 \pm 6.0$ & $32.6 \pm 4.8$ & $48.5 \pm 5.4$ & $9.4 \pm 3.2$ & $24.4 \pm 5.2$ & $34.0 \pm 2.1$ \\
\hline ANTP & $14.9 \pm 5.8$ & $35.1 \pm 3.1$ & $52.5 \pm 1.9$ & $10.2 \pm 4.5$ & $24.1 \pm 2.1$ & $32.0 \pm 2.2$ \\
\hline CAF & $15.8 \pm 2.7$ & $37.4 \pm 4.3$ & $53.9 \pm 2.1$ & $6.1 \pm 0.2$ & $23.4 \pm 2.7$ & $29.3 \pm 4.5$ \\
\hline CBZ & $12.9 \pm 4.6$ & $32.5 \pm 1.5$ & $51.0 \pm 4.4$ & $8.9 \pm 3.7$ & $22.3 \pm 2.8$ & $33.0 \pm 4.4$ \\
\hline CA & $15.2 \pm 6.2$ & $33.1 \pm 3.8$ & $54.3 \pm 6.0$ & $7.7 \pm 0.8$ & $24.3 \pm 4.9$ & $32.6 \pm 7.8$ \\
\hline DCF & $15.2 \pm 3.0$ & $35.9 \pm 1.6$ & $54.9 \pm 5.2$ & $9.9 \pm 4.1$ & $26.6 \pm 3.7$ & $36.8 \pm 0.4$ \\
\hline HHCB & $15.5 \pm 5.5$ & $35.0 \pm 2.7$ & $52.3 \pm 1.6$ & $9.8 \pm 4.1$ & $27.1 \pm 1.8$ & $36.5 \pm 0.7$ \\
\hline IBP & $14.8 \pm 6.6$ & $31.9 \pm 4.4$ & $49.0 \pm 2.4$ & $9.1 \pm 3.6$ & $27.9 \pm 4.8$ & $36.6 \pm 4.6$ \\
\hline TMP-SMX & $13.9 \pm 1.7$ & $34.0 \pm 5.1$ & $52.0 \pm 8.3$ & $6.1 \pm 0.2$ & $17.8 \pm 2.4$ & $28.1 \pm 1.9$ \\
\hline TY & $15.0 \pm 5.8$ & $34.5 \pm 3.1$ & $52.0 \pm 5.1$ & $9.0 \pm 2.9$ & $25.5 \pm 2.4$ & $34.1 \pm 2.4$ \\
\hline
\end{tabular}

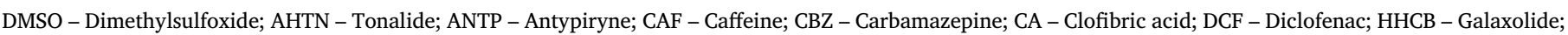
IBP - Ibuprofen; TMP - SMX - Trimethoprim - sulfamethoxazole; TY - Tylosin. 
uncommon as unrelated researchers isolated B. cepacia from DW (Simões et al., 2010; Vermis et al., 2003; Zanetti et al., 2000). Therefore, $B$. cepacia is able to survive under low nutrient conditions and in the presence of residual concentrations of chlorine, being continuously exposed to PPCPs that are present at trace concentrations (ng. $1^{-1}$ or $\mu \mathrm{g} .1^{-1}$ ) in DWDS (Carmona et al., 2014; Lardy-Fontan et al., 2017; Qiao et al., 2011; Yang et al., 2017). So, it is of utmost importance to understand the effects of the presence of emerging contaminants on the autochthonous microbiota of DWDS. This study shows that some PPCPs (ANTP, CAF, DCF, TMP - SMX) may alter NaOCl bactericidal action against $B$. cepacia. All the results were compared with the solvent control (DMSO). In fact, it was possible to observe an increase on $B$. cepacia MBC when DMSO was used. For this case, the decreased action of $\mathrm{NaOCl}$ may be caused by the reaction between DMSO and $\mathrm{NaOCl}$. Imaizumi et al. (1995) described the reaction of DMSO and $\mathrm{NaOCl}$ at a molar ratio of $1: 1$. This reaction occurs when hypochlorous acid is formed in the dissolution of chlorine in water, this acid has high redox potential and is able to oxidize DMSO (Imaizumi et al., 1995). The presence of environmental concentrations of CAF and TMP-SMX slightly decreased the bactericidal action of NaOCl. When ANTP and TMP-SMX were available at $100 \times[\mathrm{DW}]$ a more pronounced increase of MBC was observed. The changes in $B$. cepacia susceptibility to $\mathrm{NaOCl}$ may be caused by a possible reaction between the PPCPs and $\mathrm{NaOCl}$. In fact, chlorine can degrade some emerging contaminants in water (Gibs et al., 2007). Therefore, the amount of available biocide is reduced. According to the WHO (2012), SMX and TMP are included in the compounds highly removed from water by free chlorine action. Other studies described the high efficiency of chlorination on the removal of TMP and SMX (Gaffney Vde et al., 2016; Gibs et al., 2007; Glassmeyer and Shoemaker, 2005; Ramli et al., 2015). Gaffney Vde et al. (2016) studied the degradation of sulfonamides antibiotics by chlorine action and observed that $20 \%$ of SMX was degraded in the presence of $2 \mathrm{mg} \mathrm{l}^{-1}$ of free chlorine. Glassmeyer and Shoemaker (2005) also evaluated the PPCPs degradation in hypochlorite solutions $\left(28.7 \mathrm{mg}^{-1}\right.$ $\mathrm{Cl}_{2}$ ) and observed the oxidation of TMP. Also, CAF can be degraded in the presence of chlorine compounds (Sun et al., 2016), as well as DCF (Noutsopoulos et al., 2015) and ANTP (Cai et al., 2013). Therefore, in real DWDS the secondary disinfection process with chlorine may be impaired due to the presence of PPCPs at trace concentrations, decreasing its bactericidal action along the DWDS. Taking into account the possible reactions affecting the bactericidal action of $\mathrm{NaOCl}$, further analysis was performed avoiding the simultaneous presence of $\mathrm{NaOCl}$ and the PPCPs.

The prevalence of ARB in DW is also a global concern and has been frequently reported (Bergeron et al., 2015; Freitas et al., 2017; Klatte et al., 2017). Singer et al. (2016) proposed that ARB may be caused by the presence of antibiotics and other antimicrobial agents in water sources. In this study, it was found that $7 \mathrm{~d}$ of exposure to the selected PPCPs at $100 \times$ [DW], particularly CAF, TMP-SMX and TY, did not alter significantly the B. cepacia susceptibility to TMP-SMX. Several authors already correlated the spread of bacterial resistance with the exposure to antibiotics at $\mu \mathrm{g} .1^{-1}$ (Bengtsson-Palme et al., 2016; Henderson-Begg et al., 2006; Jutkina et al., 2016; López and Blázquez, 2009; Lundström et al., 2016). Nevertheless, the concentrations tested in the present work were significantly lower (ng. $1^{-1}$ or $\mu$ g. $1^{-1}$ ) than the tested in the referred studies. This trace concentrations are characteristics of PPCPs in DWDS (Table 1). The determination of a minimal concentration of a stressor that drives to antibiotic resistance has been a matter of recent research (Jutkina et al., 2016; Lundström et al., 2016). Jutkina et al. (2016) found that a very low concentration of tetracycline $\left(10 \mu \mathrm{gl}^{-1}\right)$ promoted horizontal transfer of multiple antibiotic-resistance determinants, but only higher concentrations favoured the selection of a tetracycline-resistant phenotype. Lundström et al. (2016) studied the effects of tetracycline pollution in aquatic environments on the development of bacterial resistance and observed that tetracycline significantly increased relative abundance of resistant bacteria at
$10 \mu \mathrm{g} 1^{-1}$, while specific tet genes increased significantly at $1 \mu \mathrm{g} 1^{-1}$. These studies help to understand the negligible interference of the selected PPCPs on the bactericidal action of TMP - SMX.

The presence of biofilms in the pipe walls of DWDS is also an unavoidable problem that can accelerate pipe corrosion, alter the water organoleptic characteristics and can act as a reservoir of pathogens (Reyes et al., 2008; Seth and Edyvean, 2006; Simões and Simões, 2013). These biofilms entrap microorganisms in an extracellular polymeric matrix, hindering the action of antimicrobial agents (Morton et al,, 1998). Biofilm formation depends on physical, chemical and biological interactions between bacteria and the pipe walls, where motility can play an important role in the early stages of biofilm development (Feuillie et al., 2017; Guttenplan and Kearns, 2013). It was found that the selected PPCPs had no effects on B. cepacia swimming motility. CAF and TMP-SMX reduced swarming motility, apparently due to antimicrobial action. However, DCF and HHCB increased swarming motility. Therefore, the exposure to these compounds at environmental levels, may be responsible for changes on the ability of cell movement along surfaces. These changes in the swarming differentiation may predict some effects on $B$. cepacia biofilm formation. In fact, recent studies described effects of PPCPs on biofilm communities and their structure, using pre-established biofilms from fluvial environments and wastewater treatment plants (Aubertheau et al., 2017; Proia et al., 2016; Waiser et al., 2016). In this study, the ability of B. cepacia to form biofilms in the presence of PPCPs was also evaluated. It was found that the selected PPCPs did not alter the ability of B. cepacia to form biofilms. Therefore, changes in swarming motility were not reflected in biofilm formation.

The inefficiency of residual concentrations of $\mathrm{NaOCl}\left(0.5 \mathrm{mg} \mathrm{l}^{-1}\right)$ on biofilm control may be of concern, since it can reflect what happens in real DWDS. B. cepacia biofilms formed in the presence of CBZ and TMPSMX were the most susceptible to $\mathrm{NaOCl}$ at $5 \mathrm{mg}^{-1}$, oppositely to the expected outcome from the MBC determination, as in the planktonic tests it appeared to increase B. cepacia tolerance to NaOCl. However, these facts reinforce that the simultaneous presence of $\mathrm{NaOCl}$ and PPCPs in DWDS can interfere with the disinfection process. It is likely that the presence of PPCPs may interfere with the biofilm development process, particularly with the biofilm structure, therefore influencing the biofilm susceptibility to disinfection. In fact, preliminary results (data not shown) by optical coherence tomography revealed changes of the biofilm architecture when grown in the presence of PPCPs.

\section{Conclusions}

This study provides pioneer data on the effects of selected PPCPs on $B$. cepacia planktonic and sessile behavior, including to the action of antimicrobial agents. $\mathrm{NaOCl}$ bactericidal action was reduced when in the presence of TMP-SMX, ANTP and CAF. Changes on bacterial swarming motility were caused by DCF, HHCB, CAF and TMP-SMX. The selected PPCPs had not significant effect on swimming motility, biofilm production and susceptibility to TMP-SMX. On the other hand, biofilms formed after exposure to CBZ and TMP-SMX were more susceptible to NaOCl, proposing that PPCPs may interfere with DWDS disinfection with chlorine.

\section{Acknowledgements}

This work was the result of the project: i) POCI-01-0145-FEDER006939 (LEPABE - UID/EQU/00511/2013) funded by the European Regional Development Fund (ERDF), through COMPETE2020 Programa Operacional Competitividade e Internacionalização (POCI) and by national funds, through FCT. ii) NORTE-01-0145-FEDER000005 - LEPABE-2-ECO-INNOVATION, supported by NORTE 2020, under the Portugal 2020 Partnership Agreement, through the European Regional Development Fund. iii) Grants attributed by FCT to Inês Gomes (SFRH/BD/103810/2014) and Lúcia Simões (SFRH/BPD/ 81982/2011). 


\section{Appendix A. Supplementary data}

Supplementary data related to this article can be found at http://dx. doi.org/10.1016/j.ibiod.2018.03.018.

\section{Disclosure statement}

\section{Authors declare that there is no conflict of interest.}

\section{References}

Andrews, J.M., 2001. Determination of minimum inhibitory concentrations. J. Antimicrob. Chemother. 48 (Suppl. 1), 5-16.

Aubertheau, E., Stalder, T., Mondamert, L., Ploy, M.C., Dagot, C., Labanowski, J., 2017. Impact of wastewater treatment plant discharge on the contamination of river biofilms by pharmaceuticals and antibiotic resistance. Sci. Total Environ. 579, 1387-1398.

Bengtsson-Palme, J., Hammaren, R., Pal, C., Ostman, M., Bjorlenius, B., Flach, C.F., Fick, J., Kristiansson, E., Tysklind, M., Larsson, D.G.J., 2016. Elucidating selection processes for antibiotic resistance in sewage treatment plants using metagenomics. Sci. Total Environ. 572, 697-712.

Benotti, M.J., Trenholm, R.A., Vanderford, B.J., Holady, J.C., Stanford, B.D., Snyder, S.A., 2009. Pharmaceuticals and endocrine disrupting compounds in U.S. drinking water. Environ. Sci. Technol. 43, 597-603.

Bergeron, S., Boopathy, R., Nathaniel, R., Corbin, A., LaFleur, G., 2015. Presence of antibiotic resistant bacteria and antibiotic resistance genes in raw source water and treated drinking water. Int. Biodeterior. Biodegrad. 102, 370-374.

Bergeron, S., Brown, R., Homer, J., Rehage, S., Boopathy, R., 2016. Presence of antibiotic resistance genes in different salinity gradients of freshwater to saltwater marshes in southeast Louisiana, USA. Int. Biodeterior. Biodegrad. 113, 80-87.

Berry, D., Xi, C., Raskin, L., 2006. Microbial ecology of drinking water distribution systems. Curr. Opin. Biotechnol. 17, 297-302.

Borges, A., Simões, L.C., Saavedra, M.J., Simões, M., 2014. The action of selected isothiocyanates on bacterial biofilm prevention and control. Int. Biodeterior. Biodegrad. $86,25-33$.

Boxall, A.B., Rudd, M.A., Brooks, B.W., Caldwell, D.J., Choi, K., Hickmann, S., Innes, E., Ostapyk, K., Staveley, J.P., Verslycke, T., Ankley, G.T., Beazley, K.F., Belanger, S.E., Berninger, J.P., Carriquiriborde, P., Coors, A., Deleo, P.C., Dyer, S.D., Ericson, J.F., Gagne, F., Giesy, J.P., Gouin, T., Hallstrom, L., Karlsson, M.V., Larsson, D.G., Lazorchak, J.M., Mastrocco, F., McLaughlin, A., McMaster, M.E., Meyerhoff, R.D., Moore, R., Parrott, J.L., Snape, J.R., Murray-Smith, R., Servos, M.R., Sibley, P.K., Straub, J.O., Szabo, N.D., Topp, E., Tetreault, G.R., Trudeau, V.L., Van Der Kraak, G., 2012. Pharmaceuticals and personal care products in the environment: what are the big questions? Environ. Health Perspect. 120, 1221-1229.

Brodin, T., Fick, J., Jonsson, M., Klaminder, J., 2013. Dilute concentrations of a psychiatric drug alter behavior of fish from natural populations. Science (New York, N.Y $339,814-815$

BSI, 2009. Chemical Disinfectants and Antiseptics- Quantitative Suspension Test for the Evaluation of Bactericidal Activity of Chemical Disinfectants Used in Food, Industrial, Domestic, and Institutional Areas-Test Method and Requirements British Standard Institution.

Butler, M.T., Wang, Q., Harshey, R.M., 2010. Cell density and mobility protect swarming bacteria against antibiotics. Proc. Natl. Acad. Sci. Unit. States Am. 107, 3776-3781.

Cai, M., Zhang, L., Qi, F., Feng, L., 2013. Influencing factors and degradation products of antipyrine chlorination in water with free chlorine. J. Environ. Sci. 25, 77-84.

Carmona, E., Andreu, V., Pico, Y., 2014. Occurrence of acidic pharmaceuticals and personal care products in Turia River Basin: from waste to drinking water. Sci. Total Environ. 484, 53-63.

Chaparro, C., Maurer, J., Gutierrez, C., Krajden, M., Chan, C., Winton, T., Keshavjee, S., Scavuzzo, M., Tullis, E., Hutcheon, M., Kesten, S., 2001. Infection with Burkholderia cepacia in cystic fibrosis: outcome following lung transplantation. Am. J. Respir. Crit. Care Med. 163, 43-48.

CLSI, 2015. Performance Standards for Antimicrobial Susceptibility Testing. TwentyFifth Informational Supplement. Clinical and Laboratory Standards Institute, Wayne, USA.

Conway, S.P., Brownlee, K.G., Denton, M., Peckham, D.G., 2003. Antibiotic treatment of multidrug-resistant organisms in cystic fibrosis. Am. J. Respir. Med. 2, 321-332.

Daughton, C.G., Ternes, T.A., 1999. Pharmaceuticals and personal care products in the environment: agents of subtle change? Environ. Health Perspect. 107, 907-938.

EPA, NIST, 2011. In: Agency, E.P. (Ed.), Development and Testing of Methods to Decontaminate a Building's Plumbing System Impacted by a Water Contamination Event: Decontamination of Bacillus Spores. Environment Protection Agency USA.

Ferreira, A.S., Silva, I.N., Oliveira, V.H., Becker, J.D., Givskov, M., Ryan, R.P., Fernandes, F., Moreira, L.M., 2013. Comparative transcriptomic analysis of the Burkholderia cepacia tyrosine kinase bceF mutant reveals a role in tolerance to stress, biofilm formation, and virulence. Appl. Environ. Microbiol. 79, 3009-3020.

Feuillie, C., Formosa-Dague, C., Hays, L.M., Vervaeck, O., Derclaye, S., Brennan, M.P., Foster, T.J., Geoghegan, J.A., Dufrene, Y.F., 2017. Molecular interactions and inhibition of the staphylococcal biofilm-forming protein SdrC. Proc. Natl. Acad. Sci. U.S.A. 114, 3738-3743.

Freitas, D., Silva, R.D., Bataus, L.A., Barbosa, M.S., da Silva Bitencourt Braga, C.A. Carneiro, L.C., 2017. Bacteriological water quality in school's drinking fountains and detection antibiotic resistance genes. Ann. Clin. Microbiol. Antimicrob. 16, 5.

Gaffney Vde, J., Cardoso, V.V., Benoliel, M.J., Almeida, C.M., 2016. Chlorination and oxidation of sulfonamides by free chlorine: identification and behaviour of reaction products by UPLC-MS/MS. J. Environ. Manag. 166, 466-477.

Gaffney, V.d.J., Almeida, C.M.M., Rodrigues, A., Ferreira, E., Benoliel, M.J., Cardoso, V.V., 2015. Occurrence of pharmaceuticals in a water supply system and related human health risk assessment. Water Res. 72, 199-208.

Gibs, J., Stackelberg, P.E., Furlong, E.T., Meyer, M., Zaugg, S.D., Lippincott, R.L., 2007. Persistence of pharmaceuticals and other organic compounds in chlorinated drinking water as a function of time. Sci. Total Environ. 373, 240-249.

Glassmeyer, S.T., Shoemaker, J.A., 2005. Effects of chlorination on the persistence of pharmaceuticals in the environment. Bull. Environ. Contam. Toxicol. 74, 24-31.

Guttenplan, S.B., Kearns, D.B., 2013. Regulation of flagellar motility during biofilm formation. FEMS Microbiol. Rev. 37, 849-871.

Heberer, T., Stan, H., 1996. Occurrence of polar organic contaminants in Berlin drinking water (in German). Vom Wasser 86, 19-31.

Henderson-Begg, S.K., Livermore, D.M., Hall, L.M., 2006. Effect of subinhibitory concentrations of antibiotics on mutation frequency in Streptococcus pneumoniae. J. Antimicrob. Chemother. 57, 849-854.

Henrichsen, J., Blom, J., 1975. Examination of fimbriation of some gram-negative rods with and without twitching and gliding motility. Acta Pathol. Microbiol. Scand. B 83, $161-170$.

Imaizumi, N., Kanayama, T., Oikawa, K., 1995. Effect of dimethylsulfoxide as a masking agent for aqueous chlorine in the determination of oxychlorines. Analyst (Cambridge, U.K.) 120, 1983-1987.

Johnson, S.A., Goddard, P.A., Iliffe, C., Timmins, B., Rickard, A.H., Robson, G., Handley, P.S., 2002. Comparative susceptibility of resident and transient hand bacteria to parachloro-meta-xylenol and triclosan. J. Appl. Microbiol. 93, 336-344.

Jones, O.A., Lester, J.N., Voulvoulis, N., 2005. Pharmaceuticals: a threat to drinking water? Trends Biotechnol. 23, 163-167.

Jutkina, J., Rutgersson, C., Flach, C.F., Larsson, D.G., 2016. An assay for determining minimal concentrations of antibiotics that drive horizontal transfer of resistance. Sci. Total Environ. 548-549, 131-138.

Klatte, S., Schaefer, H.-C., Hempel, M., 2017. Pharmaceuticals in the environment - a short review on options to minimize the exposure of humans, animals and ecosystems. Sustain. Chem. Pharm. 5, 61-66.

Knapp, L., Rushton, L., Stapleton, H., Sass, A., Stewart, S., Amezquita, A., McClure, P., Mahenthiralingam, E., Maillard, J.Y., 2013. The effect of cationic microbicide exposure against Burkholderia cepacia complex (Bcc); the use of Burkholderia lata strain 383 as a model bacterium. J. Appl. Microbiol. 115, 1117-1126.

Kraigher, B., Kosjek, T., Heath, E., Kompare, B., Mandic-Mulec, I., 2008. Influence of pharmaceutical residues on the structure of activated sludge bacterial communities in wastewater treatment bioreactors. Water Res. 42, 4578-4588.

Kuti, J.L., Moss, K.M., Nicolau, D.P., Knauft, R.F., 2004. Empiric treatment of multidrug resistant Burkholderia cepacia lung exacerbation in a patient with cystic fibrosis: application of pharmacodynamic concepts to meropenem therapy. Pharmacotherapy 24, 1641-1645.

Lardy-Fontan, S., Le Diouron, V., Drouin, C., Lalere, B., Vaslin-Reimann, S., Dauchy, X., Rosin, C., 2017. Validation of a method to monitor the occurrence of 20 relevant pharmaceuticals and personal care products in 167 bottled waters. Sci. Total Environ. 587-588, 118-127.

Leung, H.W., Jin, L., Wei, S., Tsui, M.M., Zhou, B., Jiao, L., Cheung, P.C., Chun, Y.K., Murphy, M.B., Lam, P.K., 2013. Pharmaceuticals in tap water: human health risk assessment and proposed monitoring framework in China. Environ. Health Perspect. $121,839-846$.

Li, X., Xu, J., de Toledo, R.A., Shim, H., 2016. Enhanced carbamazepine removal by immobilized Phanerochaete chrysosporium in a novel rotating suspension cartridge reactor under non-sterile condition. Int. Biodeterior. Biodegrad. 115, 102-109.

Liu, S., Gunawan, C., Barraud, N., Rice, S.A., Harry, E.J., Amal, R., 2016. Understanding, monitoring, and controlling biofilm growth in drinking water distribution systems. Environ. Sci. Technol. 50, 8954-8976.

Löffler, D., Römbke, J., Meller, M., Ternes, T.A., 2005. Environmental fate of pharmaceuticals in water/sediment systems. Environ. Sci. Tech. 39, 5209-5218.

López, E., Blázquez, J., 2009. Effect of subinhibitory concentrations of antibiotics on intrachromosomal homologous recombination in Escherichia coli. Antimicrob. Agents Chemother. 53, 3411-3415.

Luckenbach, T., Epel, D., 2005. Nitromusk and polycyclic musk compounds as long-term inhibitors of cellular xenobiotic defense systems mediated by multidrug transporters. Environ. Health Perspect. 113, 17-24.

Lundström, S.V., Ostman, M., Bengtsson-Palme, J., Rutgersson, C., Thoudal, M., Sircar, T. Blanck, H., Eriksson, K.M., Tysklind, M., Flach, C.F., Larsson, D.G.J., 2016. Minimal selective concentrations of tetracycline in complex aquatic bacterial biofilms. Sci. Total Environ. 553, 587-595.

Moore, J.E., Crowe, M., Shaw, A., McCaughan, J., Redmond, A.O., Elborn, J.S., 2001. Antibiotic resistance in Burkholderia cepacia at two regional cystic fibrosis centres in Northern Ireland: is there a need for synergy testing? J. Antimicrob. Chemother. 48, 319-321.

Morton, L.H.G., Greenway, D.L.A., Gaylarde, C.C., Surman, S.B., 1998. Consideration of some implications of the resistance of biofilms to biocides. Int. Biodeterior. Biodegrad. 41, 247-259.

Noutsopoulos, C., Koumaki, E., Mamais, D., Nika, M.C., Bletsou, A.A., Thomaidis, N.S., 2015. Removal of endocrine disruptors and non-steroidal anti-inflammatory drugs through wastewater chlorination: the effect of $\mathrm{pH}$, total suspended solids and humic acids and identification of degradation by-products. Chemosphere 119 (Suppl. 1), S109-S114.

Phan, H.V., Hai, F.I., Zhang, R., Kang, J., Price, W.E., Nghiem, L.D., 2016. Bacterial 
community dynamics in an anoxic-aerobic membrane bioreactor - impact on nutrient and trace organic contaminant removal. Int. Biodeterior. Biodegrad. 109, 61-72.

Prest, E.I., Hammes, F., van Loosdrecht, M.C.M., Vrouwenvelder, J.S., 2016. Biological stability of drinking water: controlling factors, methods, and challenges. Front. Microbiol. 7, 45.

Proia, L., von Schiller, D., Sanchez-Melsio, A., Sabater, S., Borrego, C.M., RodriguezMozaz, S., Balcazar, J.L., 2016. Occurrence and persistence of antibiotic resistance genes in river biofilms after wastewater inputs in small rivers. Environ. Pollut. 210, $121-128$.

Qiao, T., Yu, Z., Zhang, X., Au, D.W., 2011. Occurrence and fate of pharmaceuticals and personal care products in drinking water in southern China. J. Environ. Monit. 13, 3097-3103.

Ramli, M.R., Sulaiman, N.M., Mohd, M.A., Rabuni, M.F., 2015. Performance of chlorination process during nanofiltration of sulfonamide antibiotic. Water Sci. Technol. 72, 1611-1620.

Reasoner, D.J., Geldreich, E.E., 1985. A new medium for the enumeration and subculture of bacteria from potable water. Appl. Environ. Microbiol. 49, 1-7.

Reddersen, K., Heberer, T., Dünnbier, U., 2002. Identification and significance of phenazone drugs and their metabolites in ground- and drinking water. Chemosphere 49, 539-544.

Reyes, A., Letelier, M.V., De la Iglesia, R., González, B., Lagos, G., 2008. Microbiologically induced corrosion of copper pipes in low-pH water. Int. Biodeterior. Biodegrad. 61, 135-141.

Schriks, M., Heringa, M.B., van der Kooi, M.M., de Voogt, P., van Wezel, A.P., 2010. Toxicological relevance of emerging contaminants for drinking water quality. Water Res. 44, 461-476.

Seth, A.D., Edyvean, R.G.J., 2006. The function of sulfate-reducing bacteria in corrosion of potable water mains. Int. Biodeterior. Biodegrad. 58, 108-111.

Simões, L., Simões, M., 2013. Biofilms in drinking water: problems and solutions. RSC Adv. 3, 2520-2533.

Simões, L.C., Simões, M., Oliveira, R., Vieira, M.J., 2007. Potential of the adhesion of bacteria isolated from drinking water to materials. J. Basic Microbiol. 47, 174-183.

Simões, L.C., Simões, M., Vieira, M.J., 2010. Adhesion and biofilm formation on polystyrene by drinking water-isolated bacteria. Antonie Leeuwenhoek 98, 317-329.

Singer, A.C., Shaw, H., Rhodes, V., Hart, A., 2016. Review of antimicrobial resistance in the environment and its relevance to environmental regulators. Front. Microbiol. 7, $1728-1750$.

Snyder, S.A., 2008. Occurrence, treatment, and toxicological relevance of EDCs and pharmaceuticals in water. Ozone Sci. Eng. 30, 65-69.

Stackelberg, P.E., Furlong, E.T., Meyer, M.T., Zaugg, S.D., Henderson, A.K., Reissman, D.B., 2004. Persistence of pharmaceutical compounds and other organic wastewater contaminants in a conventional drinking-water-treatment plant. Sci. Total Environ. 329, 99-113.

Stackelberg, P.E., Gibs, J., Furlong, E.T., Meyer, M.T., Zaugg, S.D., Lippincott, R.L., 2007. Efficiency of conventional drinking-water-treatment processes in removal of pharmaceuticals and other organic compounds. Sci. Total Environ. 377, 255-272.
Stepánovic, S., Vukovic, D., Dakic, I., Savic, B., Svabic-Vlahovic, M., 2000. A modified microtiter-plate test for quantification of staphylococcal biofilm formation. J. Microbiol. Meth. 40, 175-179.

Stickland, H.G., Davenport, P.W., Lilley, K.S., Griffin, J.L., Welch, M., 2010. Mutation of nfxB causes global changes in the physiology and metabolism of Pseudomonas aeruginosa. J. Proteome Res. 9, 2957-2967.

Stumpf, M., Ternes, T.A., Haberer, K., Seel, P., 1996. Determination of drugs in sewage treatment plants and river water. Vom Wasser 86, 291-303.

Sun, P., Lee, W.-N., Zhang, R., Huang, C.-H., 2016. Degradation of DEET and caffeine under UV/chlorine and simulated sunlight/chlorine conditions. Environ. Sci. Technol. 50, 13265-13273.

Vermis, K., Brachkova, M., Vandamme, P., Nelis, H., 2003. Isolation of Burkholderia cepacia complex genomovars from waters. Syst. Appl. Microbiol. 26, 595-600.

Vernouillet, G., Eullaffroy, P., Lajeunesse, A., Blaise, C., Gagné, F., Juneau, P., 2010. Toxic effects and bioaccumulation of carbamazepine evaluated by biomarkers measured in organisms of different trophic levels. Chemosphere 80, 1062-1068.

Waiser, M.J., Swerhone, G.D., Roy, J., Tumber, V., Lawrence, J.R., 2016. Effects of erythromycin, trimethoprim and clindamycin on attached microbial communities from an effluent dominated prairie stream. EES (Ecotoxicol. Environ. Saf.) 132, 31-39.

Wang, C., Shi, H., Adams, C.D., Gamagedara, S., Stayton, I., Timmons, T., Ma, Y., 2011. Investigation of pharmaceuticals in Missouri natural and drinking water using high performance liquid chromatography-tandem mass spectrometry. Water Res. 45, $1818-1828$.

Weinberger 2nd, J., Klaper, R., 2014. Environmental concentrations of the selective serotonin reuptake inhibitor fluoxetine impact specific behaviors involved in reproduction, feeding and predator avoidance in the fish Pimephales promelas (fathead minnow). Aquat. Toxicol. 151, 77-83.

WHO, 2012. Pharmaceuticals in Drinking Water. World Health Organization, Geneva.

Wingender, J., Flemming, H.C., 2011. Biofilms in drinking water and their role as reservoir for pathogens. Int. J. Hyg Environ. Health 214, 417-423.

Wombacher, W.D., Hornbuckle, K.C., 2009. Synthetic musk fragrances in a conventional drinking water treatment plant with lime softening. J. Environ. Eng. 135, 1192

Xi, C., Zhang, Y., Marrs, C.F., Ye, W., Simon, C., Foxman, B., Nriagu, J., 2009. Prevalence of antibiotic resistance in drinking water treatment and distribution systems. Appl. Environ. Microbiol. 75, 5714-5718.

Yang, Y., Ok, Y.S., Kim, K.-H., Kwon, E.E., Tsang, Y.F., 2017. Occurrences and removal of pharmaceuticals and personal care products (PPCPs) in drinking water and water/ sewage treatment plants: a review. Sci. Total Environ. 596-597, 303-320.

Ye, Z., Weinberg, H.S., Meyer, M.T., 2007. Trace analysis of trimethoprim and sulfonamide, macrolide, quinolone, and tetracycline antibiotics in chlorinated drinking water using liquid chromatography electrospray tandem mass spectrometry. Anal. Chem. 79, 1135-1144.

Zanetti, F., De Luca, G., Stampi, S., 2000. Recovery of Burkholderia pseudomallei and B. cepacia from drinking water. Int. J. Food Microbiol. 59, 67-72.

Zuccato, E., Calamari, D., Natangelo, M., Fanelli, R., 2000. Presence of therapeutic drugs in the environment. Lancet 355, 1789-1790. 